\title{
Does the rheumatoid arthritis affect the enteric nervous system?
}

\author{
Jacqueline Nelisis ZANONI and Gleison Daion PIOVEZANA BOSSOLANI
}

Received 13/9/2018

Accepted 15/5/2019

\begin{abstract}
Background - Few studies regarding arthritic diseases have been performed to verify the presence of the neurodegeneration. Given the increased oxidative stress and extra-articular effects of the rheumatoid arthritis, the gastrointestinal studies should be further investigated aiming a better understanding of the systemic effects the disease on enteric nervous system. Objective - To determine whether the rheumatoid arthritis affects the nitrergic density and somatic area of the nNOS- immunoreactive (IR) myenteric neurons, as well as the morphometric areas of CGRP and VIPIR varicosities of the ileum of arthritic rats. Methods - Twenty 58-day-old male Holtzmann rats were distributed in two groups: control and arthritic. The arthritic group received a single injection of the Freund's Complete Adjuvant in order to induce arthritis model. The whole-mount preparations of ileum were processed for immunohistochemistry to VIP, CGRP and nNOS. Quantification was used for the nitrergic neurons and morphometric analyses were performed for the three markers. Results - The arthritic disease induced a reduction $6 \%$ in ileal area compared to control group. No significant differences were observed in nitrergic density comparing both groups. However, arthritic group yielded a reduction of the nitrergic neuronal somatic area and VIP-IR varicosity areas. However, an increase of varicosity CGRP-IR areas was also observed. Conclusion-Despite arthritis resulted in no alterations in the number of nitrergic neurons, the retraction of ileal area and reduction of nitrergic somatic and VIP-IR varicosity areas may suggest a negative impact the disease on the ENS.
\end{abstract}

HEADINGS - Rheumatoid arthritis. Enteric nervous system. Freund's adjuvant. Rats. Nitrergic neurons.

\section{INTRODUCTION}

Rheumatoid arthritis (RA) is a progressive, chronic inflammatory, autoimmune and multi-systemic disease that affects several tissues, but mainly the joints, and reaches approximately $1 \%$ of the world's population. The development of rheumatoid arthritis is associated with auto-immune and environmental factors, although its etiology is still unknown. Furthermore, the RA is characterized by the infiltration and activation of inflammatory cells in the tissues and fluids of the synovial joints ${ }^{(1-4)}$.

The complex pathogenesis of rheumatoid arthritis involves $\mathrm{T}$ cells that stimulate monocytes, macrophages and synovial fibroblasts, which lead to the production of pro-inflammatory cytokines, prostaglandins and chemokines as well as the stimulation of B cells. Pro-inflammatory mediators promote and perpetuate chronic immune-mediated inflammation of soft tissue, resulting in joint destruction ${ }^{(2,5-8)}$.

The inflammatory process of RA is mediated by cytokines (e.g. IL-1, TNF- $\alpha$, IL-1, IL-6, IL-17, etc) and reactive oxygen species (ROS) that modulates the activity of inflammatory cells ${ }^{(3,9,10)}$. The ROS is produced by activated phagocytes, with a protective function against pathogenic invaders, although these cells can promote tissue through intensifying the inflammation process ${ }^{(11)}$. Furthermore, the synthesis ROS also occurs due to the cycles of hypoxia-reperfusion during movement of the inflamed joints ${ }^{(4,7,9,12,13)}$.

The pathogenesis of RA has barely been explored in detail or in studies of the gastrointestinal wall, affecting the Enteric Nervous System (ENS). Enteric neurons have been widely investigated using experimental models that induce oxidative stress (e.g. aging, diabetes, cancer, parasitic diseases and physical activity). These studies evaluate whether the intestinal dysfunctions are associated with morphological and quantitative changes of neurons and expression of neurotransmitters by the $\mathrm{ENS}^{(14-20)}$.

Considering the complex division of the Autonomic Nervous System, the ENS displays an independent function, which is able to perform the functions of the digestive system, without relying on central nervous commands. The ENS is organized in plexuses, ganglionated and aganglionated, and enteric neurons release various neurotransmitters. Besides its neural network, the ENS also has extrinsic neuronal terminations of the sympathetic and parasympathetic nervous system, connected by afferent and efferent neuronal fibers to the Central Nervous System. The ENS may control and coordinate intestinal motility, exocrine and endocrine secretions, absorption, microcirculation and the local immune system, and modulate the inflammatory response of the gastrointestinal tract(21-23).

Enteropathies are commonly associated with loss of enteric neurons and its subpopulations such as neuronal nitric oxide synthase (nNOS). Both ganglionated plexuses of the SNE express different neuropeptides such as calcitonin gene-related peptide (CGRP) and vasoactive intestinal polypeptide (VIP). VIPergic neuropeptide promotes smooth muscle relaxation and stimulates the secretion of fluids and electrolytes and CGRP is a vasodilator neuropeptide that enhances the intestinal blood flow through stimulation of smooth muscle relaxation ${ }^{(22,24)}$. Both CGRP and VIP are considered an antioxidant and anti-inflammatory neuropeptides ${ }^{(24)}$. 
Given that poor correlation between the extra-articular effects of RA on ENS and susceptibility of enteric neurons to the RAinduced oxidative stress, the aim of this study was to investigate whether the RA affects the ENS evaluating quantitative and morphometric parameters of vasoactive intestinal polypeptide (VIP) and neuronal nitric oxide synthase (nNOS) and calcitonin gene-related peptide (CGRP).

\section{METHODS}

\section{Experimental groups}

All animals were obtained from the Central Animal Facility of the State University of Maringá and the experiments were approved by the Committee of Ethics in Animal Experimentation of the State University of Maringa.

Twenty 58-day-old male Holtzmann rats (Rattus norvegicus) were obtained and distributed into two groups $(n=10$ rats per group): control (C) and arthritic (ART). Both groups were submitted to a 60-days experimental period. The animals were kept in polypropylene cages $(40 \times 33 \times 17 \mathrm{~cm})$ for 60 days under standard laboratory conditions (cycle of $12 \mathrm{~h}$ light/12h dark) and controlled temperature $\left(24^{\circ} \mathrm{C} \pm 2^{\circ} \mathrm{C}\right)$. Water and standard rat chow (Nuvital; Nuvilab, Colombo, PR, Brazil) were available ad libitum.

Adjuvant-induced arthritis was obtained by a single intradermal injection with $100 \mu \mathrm{L}$ of a suspension of Freund's Complete Adjuvant (FCA; heat-inactivated Mycobacterium tuberculosis) suspended in mineral oil at a concentration of $0.5 \%(\mathrm{w} / \mathrm{v})$ into the left hind paw ${ }^{(25)}$.

\section{Material collection and fixation}

After 60 days of experiment, animals were anesthetized with Thiopental (40 mg kg/kg body weight; Abbott Laboratories, Chicago, IL, USA) and the ileum was collected. After tissue collection, intestinal samples were rinsed in phosphate-buffered saline (PBS 0.1M, pH 7.4; $10 \mathrm{mmol} / \mathrm{L} \mathrm{Na}_{2} \mathrm{HPO}_{4}$ and $150 \mathrm{mmol} / \mathrm{L}$ $\mathrm{NaCl}$ ), followed by incubation in Zamboni's fixative for $18 \mathrm{~h}$ at $4^{\circ} \mathrm{C}$ and then, washed in $80 \%$ alcohol. Whole-mounts were sequentially dehydrated in $95 \%$ and $100 \%$ alcohol, diaphanized in xylene and then successively rehydrated in $100 \%, 90 \%, 80 \%$ and $50 \%$ alcohol. Afterwards, ileal samples were cut along the mesenteric border and rinsed in PBS for 30 min and then, stored in PBS with $0.08 \%$ sodium azide at $4^{\circ} \mathrm{C}$. Subsequently, intestinal whole-mounts were dissected under a Stemi DV4 stereomicroscope (Zeiss, Jena, Germany) containing outer muscle layers and the myenteric plexus. Ten ileal segments were dissected and processed for the subsequent immunohistochemistry technique to the nNOS, VIP and CGRP.

\section{Immunostaining for nNOS, VIP and CGRP}

The whole-mounts preparations were initially rinsed in PBS solution of $0.5 \%$ Triton X-100 three times. Afterwards, intestinal tissues were incubated in a solution containing PBS, $0.5 \%$ Triton $\mathrm{X}-100$ and $1 \%$ BSA for $1 \mathrm{~h}$. After blocking, the intestinal tissues were incubated in specific primary antibody for the nNOS (48 h), VIP and CGRP (24 h) (TABLE 1) at room temperature (RT). The ileal tissues were rinsed in PBS three times and then, incubated with the secondary antibody (TABLE 1) for two hours at RT. After incubation, tissues were rinsed in PBS three times and mounted on slides using buffered glycerol (9:1). Negative control was performed with the omission of the primary antibody.
TABLE 1 . Primary e secondary antibodies used in the immunohistochemical techniques.

\begin{tabular}{|c|c|c|}
\hline & Source & $\begin{array}{c}\text { Immunohistochemical } \\
\text { dilution }\end{array}$ \\
\hline \multicolumn{3}{|l|}{ Primary antibody } \\
\hline $\begin{array}{l}\text { Monoclonal Mouse } \\
\text { anti-nNOS; sc-5302 }\end{array}$ & $\begin{array}{c}\text { Santa Cruz } \\
\text { Biotechnology, } \\
\text { EUA }\end{array}$ & $1: 500$ \\
\hline $\begin{array}{l}\text { Polyclonal Rabbit } \\
\text { anti-Vasoactive intestinal } \\
\text { peptide (VIP); sc-20727 }\end{array}$ & $\begin{array}{l}\text { Santa Cruz } \\
\text { Biotechnolog } \\
\text { USA }\end{array}$ & $1: 300$ \\
\hline $\begin{array}{l}\text { Polyclonal Rabbit } \\
\text { anti-Calcitonin gene-related } \\
\text { peptide (CGRP); sc-28920 }\end{array}$ & $\begin{array}{l}\text { Santa Cruz } \\
\text { Biotechnolog } \\
\text { USA }\end{array}$ & $1: 200$ \\
\hline \multicolumn{3}{|l|}{ Secondary antibody } \\
\hline $\begin{array}{l}\text { Alexa fluor } 488 \text { (Donkey } \\
\text { anti-mouse); A-21202 }\end{array}$ & $\begin{array}{l}\text { Molecular } \\
\text { Probes, } \\
\text { Invitrogen } \\
\text { USA }\end{array}$ & $1: 400$ \\
\hline
\end{tabular}

\section{Image acquisition}

All photomicrographs (30 images per animal) for nNOS, VIP and CGRP were obtained using an Olympus BX40 optical fluorescence microscope (Olympus Co., Tokyo, Japan) connected to a high-resolution 5.0 Mega Pixel Moticam ${ }^{\circledR} 2500$ camera (Motic China Group Co., Shanghai, China). Photomicrographs were recorded using Motic Images Plus 2.0ML software (Motic China Group Co.).

\section{Quantitative analysis for nNOS-immunoreactive (nNOS-IR) myenteric neurons}

The quantification of nNOS-IR myenteric neurons was performed using the images obtained from sampling the intermediate region $\left(60^{\circ}-120^{\circ}\right.$ and $\left.240^{\circ}-300^{\circ}\right)$ of the ileum circumference of each animal, considering $0^{\circ}$ as the mesenteric border ${ }^{(26)}$. The results were expressed as the number of neurons in $5.8 \mathrm{~mm}^{2}$ ileum. The neuronal density correction of the arthritic group was calculated using the measurements of intestinal length and width in comparison to control group.

\section{Morphometric analysis for nNOS-IR myenteric neurons}

The morphometric measurement of the somatic areas of nNOS-IR myenteric neurons was performed using the earlier images. The area $\left(\mu \mathrm{m}^{2}\right)$ of 100 neuronal cell bodies per animal was measured through Image-Pro Plus with a total 500 neuronal body areas per group.

\section{VIP and CGRP-IR myenteric fibers}

For the measurement of the area of the VIP and CGRP-IR varicosities, the Image-Pro-Plus was used and the areas $\left(\mu \mathrm{m}^{2}\right)$ of 400 varicosities of each animal were measured, reaching a total of 2000 varicosities per group for each technique.

\section{Statistical analysis}

Results were subjected to statistical analyses through the programs Statistica and GraphPad Prism, expressed as media \pm standard error. Morphometric data were analyzed by the MannWhitney test for non-parametric parameters. Values of $P<0.05$ were considered statistically significant. 


\section{RESULTS}

\section{Development of RA}

Arthritic animals developed the characteristic signs of the disease one week after injection. The arthritic animals exhibited edema paws with consequent locomotor difficulties. Furthermore, a reduction of water and feed intake was observed. The area of the small intestine for ART group was smaller than C group (TABLE 2). However, no significant differences were observed evaluating the length and width of the ileal samples between both groups (TABLE 2). The neuronal density was corrected in $6 \%$ for the ART group.

TABLE 2. Length, width and area of ileal samples from the control (C) and arthritic (ART) groups.

\begin{tabular}{lccc}
\hline Groups & Length $(\mathrm{cm})$ & Width $(\mathrm{cm})$ & Area $\left(\mathrm{cm}^{2}\right)$ \\
\hline C & $101.5 \pm 6.4$ & $1.56 \pm 0.26$ & $158.4 \pm 12.9$ \\
ART & $99.20 \pm 4.8$ & $1.50 \pm 0.0$ & $148.8 \pm 3.2 *$ \\
\hline
\end{tabular}

Data are expressed as mean \pm standard error. $* P<0.05$ compared to $C$ group.

\section{nNOS-IR myenteric neurons}

No significant differences $(P>0.05)$ were observed for the neuronal density comparing both studied groups (C: 159.2 66.8 ; ART: $201.5 \pm 25.2$ neurons $\left./ 5.8 \mathrm{~mm}^{2}\right)$.

For the nNOS-IR neurons, a reduction of the body cell area $(14.59 \%)$ was observed comparing C group with the ART group $(P<0.001)$. Such alteration of the somatic neuronal body area can also be observed through the frequency of cell body size distribution and mean neuronal area (FIGURE $1 \mathrm{~A}$ and $\mathrm{B}$ ). Regarding the immunostainings for the nitrergic neurons, primary, secondary and tertiary plexuses were visualized in the myenteric plexus. Most nNOS-IR neurons were present in the periphery of the ganglion, but the nitrergic neurons for some ganglia were seen in central position (FIGURE $2 \mathrm{~A}$ and $\mathrm{B}$ ).
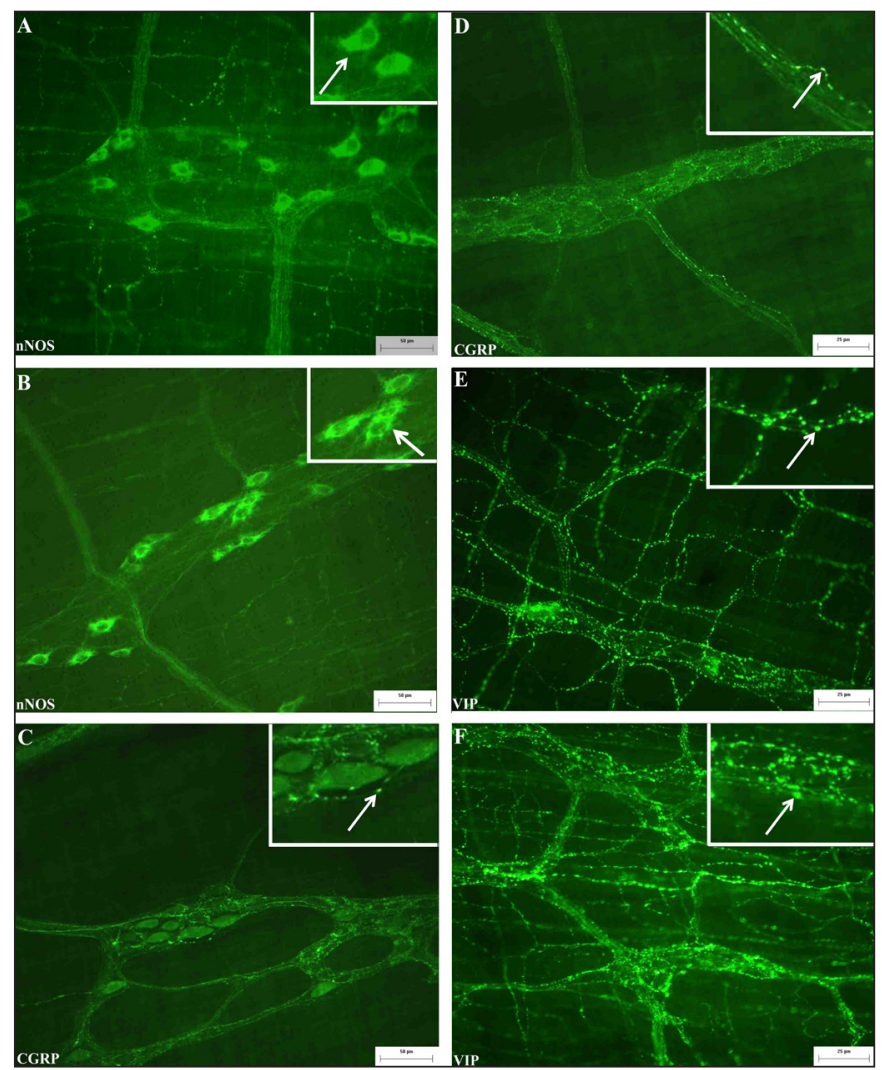

FIGURE 2. Immunohistochemical technique using the myenteric plexus for $\mathrm{nNOS}$ (A and B), CGRP (C and D) and VIP (E and F) of the ileum of arthritic rats. Figures $A, C$ and $E$ illustrate the control group and figures $\mathrm{B}, \mathrm{D}$ and $\mathrm{F}$ exhibit the arthritic group. White arrow in $\mathrm{A}$ and $\mathrm{B}$ shows cell body, in C, D, E and F shows varicosity. Scale bar $=25 \mu \mathrm{m}$.

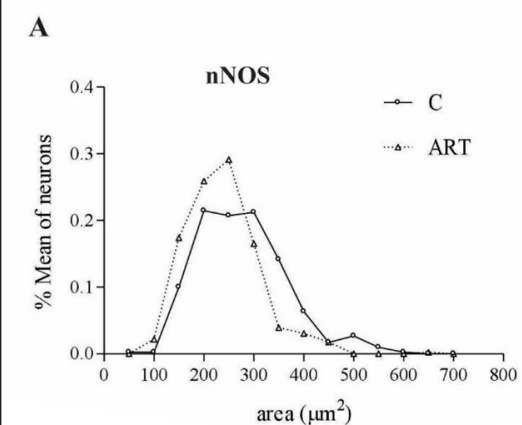

B

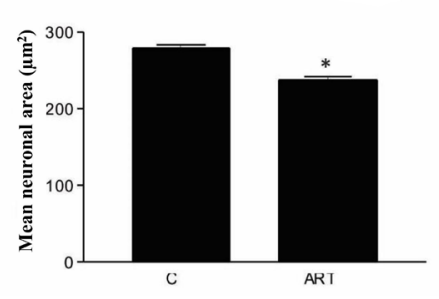

C

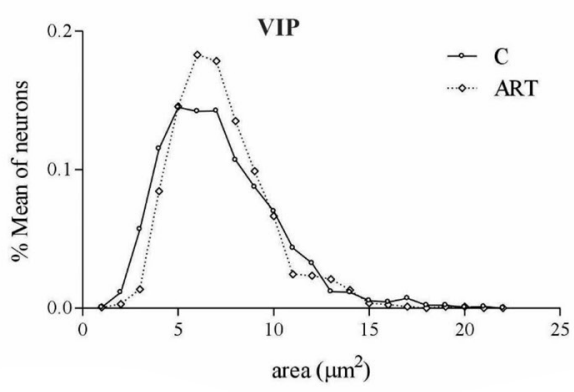

D

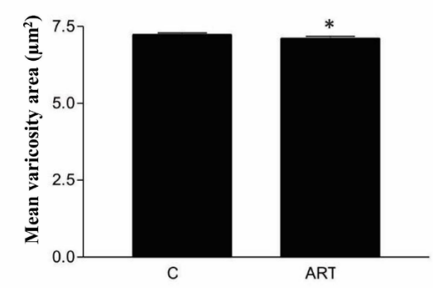

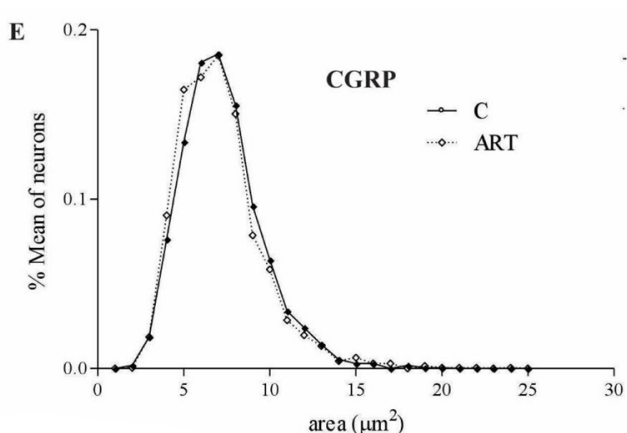

F

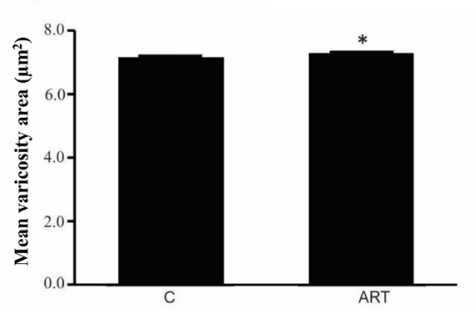

FIGURE 1. Relative frequency distribution of somatic area of nNOS-IR myenteric neurons (A) and morphometry of CGRP-IR (C) and VIP-IR (E) myenteric varicosities of the ileum of arthritic rats. Mean area of nitrergic neurons (B) and VIP-IR (D) and CGRP-IR (F) varicosity areas $\left(\mu m^{2}\right)$. 


\section{VIP-IR and CGRP-IR neuronal fibers}

For the total whole-mounts immunostained to CGRP, the presence of CGRP-IR fibers in the primary, secondary and tertiary plexuses of the myenteric region was observed. The obtained mean for the CGRP-IR varicosity area was higher for the ART group $(P<0.001$; FIGURE 1F) compared to $\mathrm{C}$ group. This difference can be observed by the frequency distribution in FIGURE 1E. Regarding the VIP-IR neuronal fibers, a high density of fibers was observed in all animals. However, the VIP-IR varicosity area in ART group was smaller compared to $C$ group $(P<0.01$; FIGURE $1 C)$. Representative photomicrographs of the immunostainings for CGRP and VIP are shown in FIGURE 2.

\section{DISCUSSION}

In this study, all features of development of RA were observed for the arthritic group: reduction of weight body, formation of paw edema and extra-articular effects. The slight retraction of ileal area of the arthritic rats suggests an atrophic effect of the disease on small intestine, likewise Souza et al. ${ }^{(27)}$ observed such effects in the jejunum and ileum. Atrophy of the intestinal area have been reported in other experimental models (e.g. diabetes mellitus, aging and cancer) ${ }^{(14,28,29)}$.

Despite no changes in nitrergic neuronal density were observed by the disease, a reduction of neuronal size of nNOS-IR neurons. Neuronal plasticity phenomena occur due to adaptation to changes of environmental factors or bowel inflammatory diseases. In the ENS, neuronal NOS-derived NO acts as neurotransmitter, which mediates the relaxing components of bowel peristalsis ${ }^{(2)}$. These phenotypic changes may indicate a compensatory mechanism to either GI dysfunctions or neurons loss in order to balance its bowel activity closer to ideal ${ }^{(30)}$. However, in our study, the reduction of somatic area of the nNOS-IR myenteric neurons suggests a negative effect induced by the AR since no alterations were observed in the nitrergic density.

The hypertrophy of the neuronal size is commonly associated with an increased enzymatic synthesis as a compensatory mechanism against the neuronal density loss, whereas the neuronal atrophy may indicate negative effects by the reduction of production of the neurotransmitter and oxidative injury induced by the disease on the ENS, resulting in a decrease of gastrointestinal function ${ }^{(28,30)}$. In our study, no nitrergic changes were observed but associated with reduction of the neuronal body area of the nNOS-IR neurons, which may also suggest an arthritis-induced harmful effect. Souza et al. ${ }^{(27)}$ reported that RA did not result in quantitative alterations on enteric nervous system, only morphometric changes in myenteric population of neurons from the ileal and jejunal tissues of Holtzmann rats induced by the FCA using an arthritis model of 30 and 60 days of experimental period. In line with Souza et al. ${ }^{(27)}$, our results demonstrated only alterations in the morphometry of the nitrergic neurons.

The ganglionated plexuses of the ENS exhibit the expression of different neuropeptides such as the VIP and CGRP, which stimulate smooth muscle relaxation ${ }^{(22,23)}$. As described earlier, both varicosity areas for CGRP and VIP were reduced, which may indicate a decrease in the production and release of these neuropeptides, thereby affecting the normal functioning of the GI tract ${ }^{(24)}$. The VIP neuropeptide has anti-inflammatory, antioxidant and anti-apoptotic effects, mainly in inflammatory and autoimmune diseases since it is capable of regulating various nuclear transduction and transcription pathways. Furthermore, the VIP is involved in mechanisms of neuroplasticity and neuroprotection, since it is considered a neurotrophic factor that stimulates the synthesis of other growth factors and inhibits cellular apoptosis induced by oxidative stress ${ }^{(31,32)}$. The CGRP is a vasodilator neuropeptide that acts in the increase of the intestinal blood flow, stimulate the smooth muscle relaxation, downregulate the inflammatory responses and participate in the pathways of pain transmission. Furthermore, CGRP has antioxidant and anti-inflammatory effects ${ }^{(22,33,34)}$. In this study, the reduction of VIP-IR varicosity areas may indicate the presence of inflammatory process in the ileum induced by the AR, which may lead to a decrease of production and release of this neuropetide ${ }^{(24,30)}$. Furthermore, NO induces the release of VIP in the myenteric plexus ${ }^{(35,36)}$, and both morphometric reductions may indicate correlations with decrease in the production of the neuronal NO and VIP.

Since VIP displays crucial roles against the inflammation and oxidative stress in the GI system, its reduction in the production and release by the varicosities suggests a negative impact of the disease. However, the increased CGRP-IR varicosity areas suggest a compensatory mechanism against the other negative impacts above described, mostly due to antioxidant and anti-inflammatory properties of this neuropeptide. Varicosity hypertrophy indicates higher production and release of the CGRP which would ameliorate the intestinal function affected by the disease ${ }^{(24,37)}$.

For these reasons, these morphometric changes in the nitrergic somatic areas and the varicosities in the myenteric plexus revealed neuroplasticity ${ }^{(37)}$ and further studies should be done to better investigate interferences of the RA in the ENS functioning.

\section{CONCLUSION}

Therefore, the retraction of intestinal area and decrease of somatic area of the nitrergic neurons and VIP-IR varicosity areas may indicate the RA-induced deleterious effects, affecting the normal functioning the GI system. However, further studies should be investigated whether the disease induces changes in the levels of oxidative stress, protein expressions, evaluated by molecular techniques, and morphology of GI wall.

\section{ACKNOWLEDGEMENTS}

We thank the technical support of Mr. Jailson Dantas Araujo, Mrs. Ana Paula de Santi Rampazzo, Mrs. Maria Euride do Carmo Cancino and Mrs. Maria dos Anjos Fortunato.

\section{Authors' contribution}

The authors participated equivalently in the intellectual content, analysis of data and in the review of the writing this article.

\section{Orcid}

Jacqueline Nelisis Zanoni. Orcid: 0000-0002-2892-5123.

Gleison Daion Piovezana Bossolani. Orcid: 0000-0001-6472-2748. 
Zanoni JN, Piovezana Bossolani GD. A artrite reumatoide afeta o sistema nervoso entérico? Arq Gastroenterol. 2019;56(2):113-7.

RESUMO - Contexto - Poucos estudos sobre doenças artríticas têm sido realizados para verificar a presença de neurodegeneração. Diante do aumento do estresse oxidativo e dos efeitos extra-articulares da artrite reumatoide, estudos gastrointestinais devem ser investigados visando uma melhor compreensão dos efeitos sistêmicos da doença no sistema nervoso entérico. Objetivo - Determinar se a artrite reumatoide afeta a densidade nitrérgica e a área somática dos neurônios mioentéricos imunorreativos ao nNOS (nNOS-IR), bem como para as áreas morfométricas das varicosidades CGRP-IR e VIP-IR do íleo de ratos artríticos. Métodos - Vinte ratos Holtzmann, com 58 dias de idade, foram distribuídos em dois grupos: controle e artrítico. O grupo artrítico recebeu uma única injeção do adjuvante completo de Freund para induzir o modelo de artrite. Os preparados totais de íleo foram processados para imuno-histoquímica ao VIP, CGRP e nNOS. A quantificação foi utilizada para os neurônios nitrérgicos e as análises morfométricas foram realizadas para os três marcadores. Resultados - A doença artrítica induziu uma redução de 6\% na área ileal em relação ao grupo controle. Não foram observadas diferenças significativas na densidade nitrérgica comparando os dois grupos. No entanto, o grupo artrítico produziu uma redução da área somática neuronal nitrérgica e da área das varicosidades do VIP-IR. Entretanto, foi observado um aumento das áreas das viricosidades CGRP-IR. Conclusão - Apesar da artrite não resultar em alterações no número de neurônios nitrérgicos, a retração da área ileal e a redução das áreas somática nitrérgica e das varicosidades do VIP-IR podem sugerir um impacto negativo da doença no sistema nervoso entérico.

DESCRITORES - Artrite reumatoide. Sistema nervoso entérico. Ratos. Adjuvante de Freund. Neurônios nitrérgicos.

\section{REFERENCES}

1. Kumar VS, Kumar DA, Kalaivani K, Gangadharan AC, Raju KV, Thejomoorthy $\mathrm{P}$, et al. Optimization of pulsed electromagnetic field therapy for management of arthritis in rats. Bioelectromagnetics. 2005;26:431-9.

2. Kahlenberg JM, Fox DA. Advances in the medical treatment of rheumatoid arthritis. Hand Clin. 2011;27:11-20.

3. Choy E. Understanding the dynamics: pathways involved in the pathogenesis of rheumatoid arthritis. Rheumatology (Oxford). 2012;51:v3-11.

4. Smolen JS, Aletaha D, McInnes IB. Rheumatoid arthritis. Lancet. 2016;388:2023-38.

5. Silva KN, Mizusaki Imoto A, Almeida GJ, Atallah AN, Peccin MS, Fernandes Moça Trevisani V. Balance training (proprioceptive training) for patients with rheumatoid arthritis. Cochrane Database Syst Rev. 2010: CD007648.

6. McInnes IB, Schett G. The pathogenesis of rheumatoid arthritis. N Engl J Med. 2011:365:2205-19.

7. Smolen JS, Aletaha D, Redlich K. The pathogenesis of rheumatoid arthritis: new insights from old clinical data? Nat Rev Rheumatol. 2012;8:235-43.

8. Angelotti F, Parma A, Cafaro G, Capecchi R, Alunno A, Puxeddu I. One year in review 2017: pathogenesis of rheumatoid arthritis. Clin Exp Rheumatol. 2017;35:368-78.

9. Hitchon CA, El-Gabalawy HS. Oxidation in rheumatoid arthritis. Arthritis Res Ther. 2004;6:265-78

10. Mirshafiey A, Mohsenzadegan M. The role of reactive oxygen species in immunopathogenesis of rheumatoid arthritis. Iran J Allergy Asthma Immunol. 2008;7:195-202.

11. Babior BM. Phagocytes and oxidative stress. Am J Med. 2000;109:33-44.

12. Mateen S, Moin S, Khan AQ, Zafar A, Fatima N. Increased Reactive Oxygen Species Formation and Oxidative Stress in Rheumatoid Arthritis. PLoS One 2016;11:e0152925.

13. Veselinovic M, Barudzic N, Vuletic M, Zivkovic V, Tomic-Lucic A, Djuric D, Jakovljevic V. Oxidative stress in rheumatoid arthritis patients: relationship to diseases activity. Mol Cell Biochem. 2014;391:225-32.

14. Zanoni JN, de Miranda-Neto MH, Bazotte RB, de Souza RR. Morphological and quantitative analysis of the neurons of the myenteric plexus of the cecum of streptozotocin diabetic rats. Arq Neuropsiquiatr. 1997;55:696-702.

15. Maifrino LBM, Prates JC, De Souza RR, Liberti EA. Morphometry and acetylcholinesterase activity of the myenteric plexus of the wild mouse Calomys callosus. Braz J Med Biol Res. 1997;30:627-32.

16. Fregonesi CE, de Miranda-Neto MH, Molinari SL, Zanoni JN. Quantitative study of the myenteric plexus of the stomach of rats with streptozotocin-induced diabetes. Arq Neuropsiquiatr. 2001;59:50-3.

17. Furlan MM, Molinari SL, Miranda Neto MH. Morphoquantitative effects of acute diabetes on the myenteric neurons of the proximal colon of adult rats. Arq Neuropsiquiatr. 2002;60:576-81.

18. Marega P, Liberti EA, Freitas JJS, Kietzer KS. Walker-256 tumor alters morphology of intestinal myenteric plexus in rats. Neurogastroenterol Motil. 2018. doi: $10.1111 / \mathrm{nmo} .13322$.

19. De Britto Mari R, Clebis NK, Gagliardo KM, Guimarães JP, Stabille SR, De Mello Germano R, De Souza RR. Effects of Exercise on the Morphology of the Myenteric Neurons of the Duodenum of Wistar Rats during the Ageing Process. Anat Histol Embryol. 2008;37:289-95

20. Alves EP, Alves AM, Pereira RV, de Miranda Neto MH, Zanoni JN. Immunohistochemical study of vasoactive intestinal peptide (VIP) enteric neurons in diabetic rats supplemented with L-glutamine. Nutr Neurosci. 2010;13:43-51.
21. Gershon MD. The enteric nervous system: a second brain. Hosp Pract (1995). 1999;34:31-2

22. Furness JB. The organisation of the autonomic nervous system: peripheral connections. Auton Neurosci. 2006;130:1-5.

23. Furness JB. The enteric nervous system and neurogastroenterology. Nat Rev Gastroenterol Hepatol. 2012;9:286-94.

24. Vicentini GE, Fracaro L, de Souza SR, Martins HA, Guarnier FA, Zanoni JN. Experimental Cancer Cachexia Changes Neuron Numbers and Peptide Levels in the Intestine: Partial Protective Effects after Dietary Supplementation with L-Glutamine. PLoS One. 2016;11:e0162998.

25. Pearson CM, Wood FD. Studies of arthritis and other lesions induced in rats by the injection of mycobacterial adjuvant: VII. Pathologic details of the arthritis and spondylitis. Am J Pathol. 1963;42:73-95.

26. Zanoni JN, De Freitas P, Pereira RV, Dos Santos Pereira MA, De Miranda-Neto MH. Effects of supplementation with ascorbic acid for a period of 120 days on the myosin-V and NADPHd positive myenteric neurons of the ileum of rats. Anat Histol Embryol. 2005;34:149-53.

27. Souza ID, Ribeiro JS, Bersani-Amado CA, Zanoni JN. Analysis of myosin-V immunoreactive myenteric neurons from arthritic rats. Arq Gastroenterol. 2011;48:205-10.

28. Johnson RJR, Schemann M, Santer RM, Cowen T. The effects of age on the overall population and on sub-populations of myenteric neurons in the rat small intestine. J Anat. 1998;192:479-88.

29. Förstermann U, Sessa WC. Nitric oxide synthases: regulation and function. Eur Heart J. 2012;33:829-37.

30. de Souza SR, de Miranda Neto MH, Martins Perles JV, Vieira Frez FC, Zignani I, Ramalho FV, Hermes-Uliana C, et al. Antioxidant Effects of the Quercetin in the Jejunal Myenteric Innervation of Diabetic Rats. Front Med (Lausanne). 2017;4:8.

31. Mario Delgado, Daid Pozo, Doina Ganea. The Significance of Vasoactive Intestinal Peptide in Immunomodulation. Pharmacol Rev. 2004;56:249-90.

32. Brenneman DE. Neuroprotection: a comparative view of vasoactive intestinal peptide and pituitary adenylate cyclase-activating polypeptide. Peptides 2007;28:1720-6.

33. Holzmann B. Modulation of immune responses by the neuropeptide CGRP. Amino acids 2013; 45:1-7.

34. Wu Y, Hao GM, He J, Lv TT, Wang HL, Mao YQ, et al. Lentivirus mediated over expression of CGRP inhibited oxidative stress in Schwann cell line. Neuroscience Letters. 2015;598:52-8.

35. Kurjak M, Fritsch R, Saur D, Schusdziarra V, Allescher HD. Functional coupling between nitric oxide synthesis and VIP release within enteric nerve terminals of the rat: involvement of protein kinase $\mathrm{G}$ and phosphodiesterase 5. J Physiol. 2001;534:827-36

36. Zanoni JN, Hernandes L, Bazotte RB, Miranda Neto MH. Terminal ileum submucous plexus: Study of the VIP-ergic neurons of diabetic rats treated with ascorbic acid. Arq. Neuropsiquiatr. 2002;60:28-31.

37. Soares A, Beraldi EJ, Ferreira PEB, Bazotte RB, Buttow NC. Intestinal and neuronal myenteric adaptations in the small intestine induced by a high-fat diet in mice. BMC Gastroenterol. 2015;15:3.

(cc) $\mathrm{BY}-\mathrm{NC}$ 